\title{
Interference of volunteer corn on soybean cultivars growth and yield
}

\author{
Fernanda Cassiane Caratti', Fabiane Pinto Lamego², Mario Antonio Bianchi \\ Joanei Cechin', Humberto Farias' ${ }^{1}$ Bruno Moncks da Silva ${ }^{1}$
}

\author{
'Federal University of Pelotas, Pelotas, Brazil \\ ${ }^{2}$ Brazilian Agricultural Research Corporation, Bagé, Brazil \\ ${ }^{3}$ Cooperativa Central Gaúcha Ltda, Cruz Alta, Brazil \\ *Corresponding author, e-mail: nandacaratti@yahoo.com.br
}

\begin{abstract}
Spontaneous corn plants in soybean crop are considered weeds because they compete for the same environmental resources. The objective of this study was to evaluate the competitive ability of soybean cultivars when in coexistence with spontaneous corn plants. A field experiment was conducted in CCGLTEC, Cruz Alta/RS, in 2014/15, in a split-plot design, with the main plot being composed of four different cultivars (CD 2694, BMX 7166 , TEC 5718, TEC 6029) and the subplots of interference conditions (without the presence of corn volunteer plants, in the presence of corn until the $V_{3^{\prime}} V_{6^{\prime}} V_{9}$ stages, or for the entire soybean cycle. Leaf area, shoot dry mass, plant height, chlorophyll index, and development stage were determined at 15, 30, and 49 DAE; we also determined apparent biological productivity, apparent harvest index, and components of productivity and grain yield. The cultivars showed losses in leaf area and shoot dry mass when in coexistence with corn (8 plants $\mathrm{m}-2$ ) in the three periods evaluated. All cultivars showed losses in apparent biological productivity, apparent harvest index, and final grain yield when growing under competition throughout the cycle. Cultivars with a medium/long growth cycle, such as CD 2694 (maturity groups (GM): 6.9) and BMX 7166 (GM: 6.6), show a higher competitive ability up to $V_{9}$, stage in contrast to cultivars with a short cycle, such as TEC 5718 (GM: 5.9) and TEC 6029 (GM: 5.7).
\end{abstract}

Keywords: Glycine max, Zea mays, interference, time of control, volunteer plant

\section{Introduction}

The sustainability of the agricultural activity is the result of the planning of the productive system of the crop, which starts with the installation of the crop until its commercialization. Integrated weed management (IWM) allows the use of diverse tools such as chemical, physical and cultural control, avoiding interference by other species, favoring the crop to obtain high yield levels. Among these IWM tools, the use of cultivars with greater competitive ability, capable of causing weed suppression, is an excellent option, promoting to reduce yield losses due to interference from other species.

The morphological and physiological characteristics of the crop are determinant in their competitive ability and can be used as a complementary tool in the IWM, thus reducing the dependence of the chemical control (Lamego et al., 2013).

Among these morphological characteristics, height is important because it gives the soybeans a competitive capacity to the plants, and the larger it is, the higher the reduction in the quantity and quality of the light incident on competitors of lower plant height than soybeans plants (CARATTI et al., 2016). However, in the case of corn volunteer plants, these have advantages because they have a canopy architecture 
that differs from soybean and gives it superior competitive ability, reducing the light quality that affects it (CARATTl et al., 2016).

With the development of genetically modified soybean cultivars resistant to glyphosate, weed management somehow has lost its importance. However, the continuous use of glyphosate may, over time, lead to the emergence of resistant biotypes (Correia \& Durigan, 2010). Currently, the Roundup Ready ${ }^{\circledR}$ (RR) technology is being incorporated into corn crops; however, in successive crops, volunteer plants (individuals of predecessor crops) emerge within the cultivation and compete for resources, resulting in additional costs. For example, a high competitive capacity of volunteer corn in soybean crops has been observed, with a corn density of two to four plants per $\mathrm{m}^{2}$, reducing soybean yield by up to 50\% (EMBRAPA, 2013).

The interference between plants can alter some agronomic characteristics and affect the yield components. Crops with an increased plant height and leaf area index, resulting in a higher interception of photosynthetically active radiation and increased dry matter production, facilitate weed management (Rigoli et al., 2008). In soybean, a higher plant heigth as well as a higher number and length of branches contribute to an increased competition capacity (Bianchi et al., 2006). However, studies on modern soybean cultivars in terms of optimizing the production system are rare, although the use of cultivars with a short cultivation cycle, indeterminate habit growth and a short medium/high plant height can present an advantage.

The present study is based on the hypothesis that there is variability in morphophysiological characteristics of soybean cultivars when coexisting with corn volunteers plants, allowing the selection of cultivars with better competitive ability. Thus, the objective of the study was to evaluate the competitive ability of soybean cultivars, in coexistence with corn volunteers plants, for different periods.

\section{Material and Methods}

The field experiment was carried out from November 2014 to April 2015 in the experimental area of the Cooperativa Central Gaúcha Ltda - CCGLTEC, Cruz Alta, RS. The soil of the experimental area is classified as a typical dystrophic Red Latosol (Santos et al., 2013). According to the results of the soil analysis, the soil had the following properties: clay, $54 \%$; $\mathrm{pH}$, 5.7 (in water); $\mathrm{PH}$ SMP, 6; O M, 3\%; $\mathrm{P}, 16.9 \mathrm{mg} \mathrm{L}^{-1}$; $\mathrm{K}, 288 \mathrm{mg} \mathrm{L}^{-1} ; \mathrm{Al}, 0$ cmolc L-1; Ca, $5.9 \mathrm{cmolc} \mathrm{L}^{-1}$;

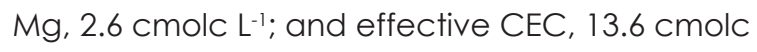
$L^{-1}$. According to the classification of Köppen, the climate in the region is humid subtropical, without typical droughts; average annual precipitation is $1,600 \mathrm{~mm}$, with an average temperature of $20^{\circ} \mathrm{C}$ (Moreno, 1961). Figure 1 shows the precipitation during the experimental period.

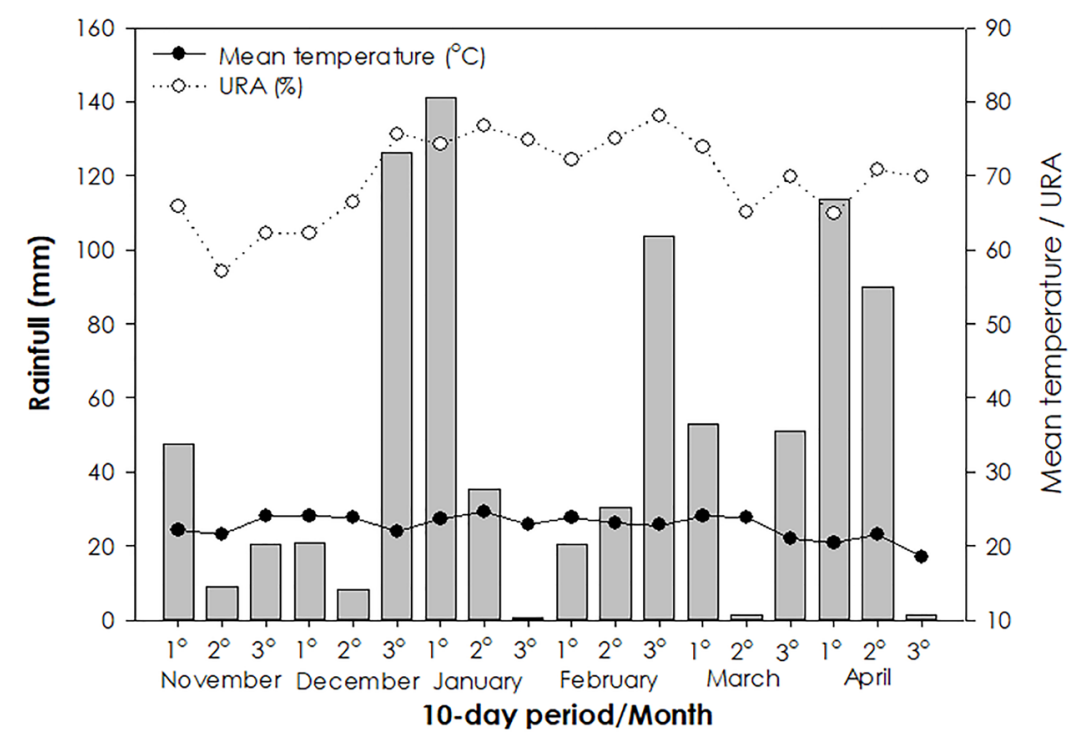

Figure 1. Rainfall during the 1st, 2nd, and 3rd ten-day period within the months of the experiment in the Cooperativa Central Gaúcha Ltda-CCGLTEC, Cruz Alta, RS, 2014/2015. 
Prior to the experiment, the glyphosate (900 $\left.\mathrm{g} \mathrm{ha}^{-1} \mathrm{a}^{-1}\right)$ and 2,4-D (1,005 $\left.\mathrm{g} \mathrm{ha}^{-1} \mathrm{a}^{-1}\right)$ herbicides were used in the area. Soybean cultivars were mechanically sown on November 22, 2014, using $0.45 \mathrm{~m}$ line spacing, targeting a plant density of 300,000 plants $\mathrm{ha}^{-1}$. The soybean cultivars used for this experiment were: TEC 5718 IPRO (short plant heigth, determinate growth, short cycle/5.9), CD 2694 IPRO (medium/high plant heigth, determinate growth, medium/long cycle /6.9), TEC 6029 IPRO (medium/high plant heigth, indeterminate growth, short cycle/5.7), and BMX 7166 RSF IPRO (high plant heigth, indeterminate growth, medium cycle/6.6).

After sowing, corn (population F2 of the hybrid AG7000YGRR2) was manually sown between the lines in a aleatory way, simulating spontaneous plant growth. At 15 days after sowing (DAS), the corn plants were thinned to obtain the desired density of 8 plants $\mathrm{m}^{-2}$, based on the study developed by Marquardt et al. (2012). These authors studied the interference of voluntary corn populations in soybean, where the most significant losses occurred up to the population of 8 plants $\mathrm{m}^{-2}$, for higher populations a tendency of stability was observed.

The experimental design was a randomized block design in split plots with four replications which the soybean cultivars were consisted the plots. The conditions evaluated were (the absence of interference, interference with volunteer corn plants up to the $V_{3^{\prime}}, V_{6^{\prime}}, V_{\text {q }}$ soybean phenological stages and interference throughout the cycle) that were allocated to the subplots.

Each experimental unit covered an area of $10.8 \mathrm{~m}^{2}(1.80 \times 6.0 \mathrm{~m})$, and the evaluations were performed in the central lines of each plot, discarding the area $0.25 \mathrm{~m}$ of the border. Corn control was performed through manual picking. In the first control (soybean in the $V_{3}$ stage), the plants had two to three leaves, while in the second and third control $\left(V_{6}\right.$ and $\left.V_{9}\right)$, the corn plants had five to six and eight to nine leaves, respectively. Other weed species in the experimental field were controlled with glyphosate.

In the treatments without interference and with interference throughout the cycle, evaluations were performed at 15,30, and 49 days after emergence (DAE), harvesting soybean plants in $0.5 \mathrm{~m}$ from the line and evaluating the following variables: growth stage (GS); plant height (PH); leaf area (LA); chlorophyll index, and shoot dry matter (SDM), these variables were not evaluated for periods of coexistence (soybean stages $V_{3}, V_{6}, V_{9}$ ). For the soybean stages $R 7$ and $R 8$, evaluations were performed to determine the apparent biological productivity (ABP - $g$ plant ${ }^{-1}$ ) (based on the scale proposed by Costa \& Marchezan, 1982) and the apparent harvest index (AHI - \%).

Five plants were sequentially collected in a row of soybeans in an area not designed for grain yield to obtain the ABP, by measuring the area of soil filled by the sample. The plants were oven dried at $60^{\circ} \mathrm{C}$ until constant mass was obtained and then weighed. The ABP comprised the sum of the shoot dry mass of the plants, including pods and grains. The division of the dry mass of the grains by the apparent biological production provided the AHI (expressed in percentage).

For the evaluation of the yield components, 10 plants were harvested from each plot to determine plant height, number of pods per plant, and number of grains per plant. In addition, we determined the number of branches per plant. Grain yield $\left(\mathrm{kg} \mathrm{ha}^{-1}\right)$ was determined by harvesting plants from an area of $2.70 \mathrm{~m}^{2}$ (two rows with a length of $3 \mathrm{~m}$ ); moisture correction was $13 \%$.

The obtained data were tested for the normality by Shapiro Wilk test ( $p \geq 0.05$ ), and no transformation was required. Subsequently, analysis of variance (ANOVA) was performed using the F-test; in the case of a significant difference between means treatments, was performed by the Tukey test at a $5 \%$ probability level $(p \leq 0.05)$.

\section{Results and Discussion}

No interactions between cultivars and interference conditions were observed $(p \geq 0.05)$ for plant height (PH) at 15 and 30 DAE. However, at $30 \mathrm{DAE}$, only for the factor of interference conditions was significant (Table 1).

Soybean plants living with corn showed an increase in plant height by $15 \%$ compared 
Table 1. Plant height (PH) at 30 and 49 days after emergence (DAE) in BMX 7166, CD 2694, TEC 5718, and TEC 6029 soybean cultivars as a function of intereference conditions: total control (absence of corn during the entire cycle) and without control (presence of corn during the entire cycle). Cooperativa Central Gaúcha Ltda - CCGL TEC, Cruz Alta, RS, 2014/2015

\begin{tabular}{|c|c|c|}
\hline Interference & \multicolumn{2}{|c|}{$\mathrm{PH}(\mathrm{cm})-30 \mathrm{DAE}$} \\
\hline Total control & \multicolumn{2}{|c|}{$27.71^{*}$} \\
\hline Without control & \multirow{2}{*}{\multicolumn{2}{|c|}{$\begin{array}{l}32.27 \\
28.99\end{array}$}} \\
\hline Mean & & \\
\hline $\mathrm{CV}^{2}(\%)$ & \multicolumn{2}{|c|}{11.45} \\
\hline \multirow[t]{2}{*}{ Cultivars } & \multicolumn{2}{|c|}{$\mathrm{PH}(\mathrm{cm})-49 \mathrm{DAE}$} \\
\hline & Total control & Without control \\
\hline TEC 5718 & $69.48 \mathrm{~A} \mathrm{~b}^{1}$ & $81.74 \mathrm{~B} \mathrm{a}$ \\
\hline CD 2694 & $67.34 \mathrm{~A} \mathrm{~b}$ & $105.06 \mathrm{~A} \mathrm{a}$ \\
\hline TEC 6029 & $70.73 \mathrm{~A} \mathrm{~b}$ & $85.96 \mathrm{~B} \mathrm{a}$ \\
\hline BMX 7166T & $70.51 \mathrm{~A} \mathrm{a}$ & $77.59 \mathrm{~B} \mathrm{a}$ \\
\hline Mean & & \\
\hline C.V. (\%) & & \\
\hline
\end{tabular}

letters, compared in the lines, between the conditions of interference significantly differ by Tukey's test $(p \leq 0.05)$. 2 Coefficient of variation.

to plants not subjected to interference; at 30 $\mathrm{DAE}$, soybean then reacted to the interference caused by spontaneous corn. Higher plants tend to absorb more red light $(R)$ and reflect far-red light (FR), which alters the R/FR ratio, reducing the light quality for lower plants in the canopy and causing etiolation (Ballaré, 2014).

When compared to soybean, corn plants show a different morphology with a higher plant heigth, facilitating higher $R$ absorption and FR reflection, thus altering the R/FR ratio. Thus, the height of co-occurring soybean plants increases, a process known as shade avoidance syndrome (Franklin, 2008; Ballaré, 2009). Therefore, it is observed that the etiolation of the stem resulted from the competition for quantity and light quality, due to the proximity of plants of different species, being also of the same species, compromising the increment of leaf area, as there is interference in the formation and growth of the leaves (WU et al., 2012). In addition, due to the increase in the production of auxins, responsible for the stem elongation in order to reach an environment with a higher light quality, there is also a reduction in the production of jasmonic acid and salicylic acid making the plant more predisposed to attack by insect pests and phytopathogenic microorganisms (Ballaré, 2014).

The decrease in the light quality is recognized by the plants, resulting in a change in their morphology. In situations when environmental resources, such as light, water, and nutrients, are in excess, the interference of weeds in terms of changing the light quality becomes the critical factor in determining the adverse effects of interspecific competition between plants (Merotto JR et al., 2009).

Observed a significant interaction between the factors cultivars and interference conditions ( $\mathrm{p} \leq 0.05)$ for PH at 49 DAE (Table 1). In the absence of corn, the cultivars presented, on average, similar PH levels. However, under coexistence, CD 2694 (mean/high height, determinate growth, medium/long cycle) had a significantly higher $\mathrm{PH}$ than the other cultivars (Table 1). The morphological characteristics of CD 2694 (medium/high height) follow BMX 7166 (high height) and TEC 6029 (medium/ high height) cultivars; however, CD 2694 cultivar had a more significant increase in plant heigth at 49 DAE in coexistence with corn plants, allowing to infer that it presents a lower tolerance to corn interference, being more predisposed to morphological alterations.

At 49 DAE and with coexistence with corn, a significant increase in $\mathrm{PH}$ was observed for the CD 2694 (36\%), TEC 6029 (17\%), and TEC 5718 (15\%) compared to the results obtained without interference. However, cultivar BMX 7166 showed no significant difference in $\mathrm{PH}$ when subjected to corn (Table 1). The increase in the height of the first three cultivars mentioned above shows that they alter their morphological characteristics in an attempt to find an environment of higher light quality. Contrarily, the BMX cultivar does not 
change its height, which leads one to understand that it tends to be more adapted to the imposed condition.

The increase of LA at 15 and 30 DAE was higher for the soybean plants without interference (Table 2). The cultivars under coexistence, with corn showed, on average, a lower LA formation, equivalent to $11 \%$ at 15 DAE and $16 \%$ at 30 DAE. Comparing the higher $\mathrm{PH}$ observed at $30 \mathrm{DAE}$ for the cultivars under interference with corn (Table 1), with the lowest increase of LA for the same interference situation, the damage caused by interference with corn became evident. Possibly, in this situation, soybean plants used higher amounts of photoassimilates for the stem etiolation, resulting in a lower final increase in LA. Thus, competition for light, both in terms of quantity, may be the result of the close proximity of plants of different species as well as of plants of the same species, compromising an increase in leaf area due to interferences in leaf formation and growth (Wu et al., 2012).

Table 2. Leaf area (LA) at 15 and 30 days after emergence (DAE) and shoot dry matter (SDM) at 15, 30, and 49 DAE of the BMX 7166, CD 2694, TEC 5718, and TEC 6029 soybean cultivars as a function of interference conditions: total control (absence of spontaneous corn) and without control (presence of corn during the whole cycle). Cooperativa Central Gaúcha Ltda - CCGLTEC, Cruz Alta, RS, 2014/2015

\begin{tabular}{|c|c|c|c|c|c|}
\hline \multirow[t]{2}{*}{ Interference } & \multicolumn{2}{|c|}{ LA $\left(\mathrm{cm}^{-2}\right.$ plant $\left.^{-1}\right)$} & \multicolumn{3}{|c|}{ SDM (g plant ${ }^{-1}$ ) } \\
\hline & $15 \mathrm{DAE}$ & $30 \mathrm{DAE}$ & $15 \mathrm{DAE}$ & $30 \mathrm{DAE}$ & $49 \mathrm{DAE}$ \\
\hline Total control & $114.41 *$ & $770.95 *$ & $0.80^{*}$ & $4.25^{*}$ & $21.89 *$ \\
\hline Without control & 102.05 & 648.27 & 0.67 & 3.43 & 12.24 \\
\hline Mean & 108.23 & 727.60 & 19.81 & 15.07 & 17.07 \\
\hline $\mathrm{CV}^{2}(\%)$ & 13.59 & 12.98 & 0.73 & 3.84 & 15.19 \\
\hline Cultivar & \multicolumn{5}{|c|}{ LA 30 DAE $\left(\mathrm{cm}^{-2}\right.$ plant $\left.{ }^{-1}\right)$} \\
\hline TEC 5718 & \multicolumn{5}{|c|}{$649.96 b^{1}$} \\
\hline CD 2694 & \multicolumn{5}{|c|}{$773.59 \mathrm{ab}$} \\
\hline TEC 6029 & \multicolumn{5}{|c|}{$828.10 \mathrm{a}$} \\
\hline BMX 7166 & \multicolumn{5}{|c|}{$658.76 \mathrm{~b}$} \\
\hline Mean & \multicolumn{5}{|c|}{727.60} \\
\hline $\mathrm{CV}^{2}(\%)$ & \multicolumn{5}{|c|}{12.98} \\
\hline
\end{tabular}

At 30 DAE, cultivar TEC6029 presented a higher LA compared to the BMX 7166 and TEC 5718 cultivars, accumulating $20 \%$ and $26 \%$ more LA, respectively (Table 2). However, there was no difference compared to cultivar CD 2694, which also did not differ from the others. The intrinsic characteristics of the TEC 5718 cultivar as low height, determined growth habit, and short cycle, are important factors that can be related to the lower accumulation of leaf area.

In terms of shoot dry mass (SDM), the cultivars growing under interference showed significantly reduced values (Table 2); at 15 DAE, the average decrease in SDM was $16 \%$, decreasing to $19 \%$ at $30 \mathrm{DAE}$ and to $44 \%$ at $49 \mathrm{DAE}$ when compared to growth without interference. We emphasize that corn, when growing in coexistence with soybean, causes damage as early as $15 \mathrm{DAE}$; it should be noted that corn is a highly competitive plant and significantly damages crops throughout the entire growing season.

A previous study evaluating the competition of volunteer corn plants in soybean crop has observed biomass reductions of 7 and $39 \%$ when soybean competed with plants at a density of 0.5 and 16 corn plants $\mathrm{m}^{-2}$, respectively (Marquardt et al., 2012). These reductions can be explained by the higher height of corn plants; in addition, corn is a C4 plant and therefore has several advantages when competing with C3 plants such as soybean, for example: plants of group $\mathrm{C}_{4}$ saturate with light intensity around $80 \%$, being radiant flux density higher than those of group $\mathrm{C}_{3}$ that tend to saturate with $30 \%$ total intensity of sunlight; the optimal temperature for fixing $\mathrm{CO}_{2}$ to $\mathrm{C}_{3}$ is around $20^{\circ} \mathrm{C}$, but for $\mathrm{C}_{4}$ it is between 30 and $40{ }^{\circ} \mathrm{C}$; $\mathrm{C}_{4}$ plants are more efficient in water use, requiring two or three times less water to produce one gram of dry matter 
than $\mathrm{C}_{3}$ species (Lopes \& Lima, 2015). These characteristics favor $\mathrm{C}_{4}$ plants mainly in adverse conditions such as high temperatures and low soil moisture, conditions commonly observed in summer crops.

As an adaptation mechanism, $\mathrm{C}_{4}$ species, in this case corn, developed the ability to accumulate $\mathrm{CO}_{2}$ around the rubisco, reducing its oxygenase activity. This process occurs in two distinct cell types, the mesophyll cells and the sheath cells of the vascular bundle, a structure known as the Kranz anatomy. Due to this $\mathrm{CO}_{2}$ concentration mechanism $\mathrm{C}_{4}$ plants are photosynthetically more efficient than $C_{3^{\prime}}$ especially in environments with high temperature, water deficit and high radiation. Even under these stress conditions, and with the stomata closed, they continue their photosynthetic activity, since they have $\mathrm{CO}_{2}$ reserves in the follicular cells in the form of organic acids (Taiz \& Zeiger, 2013).

Therefore, many characteristics that confer advantages to corn are highlighted because it is a $C_{4}$ plant, allowing to excel in situations of coexistence with $\mathrm{C}_{3}$ soybean. A study evaluating the relative competitiveness of
$\mathrm{C}_{4}$ physiological grassgrass (Echinochloa crusgalli) with the soybean cultivar BMX Apollo RR showed competitive superiority of the weed in relation to the crop based on the plant heigth of plants (Bastiani et al. 2016). Ricegrass plants in competition with rice cultivars, regardless of the proportion of plants in the association, presented lower loss of relative grain yeld, reducing the morphological variables of the rice and demonstrated to have competitive superiority, compared to rice cultivars (Agostinetto et al. 2008).

At 49 DAE and without interference, an increase of LA was observed for the BMX 7166 and TEC 5718 cultivars (Table 3). However, under interference, there was no difference between the cultivars, which allows to infer that greater competitiveness is exerted by corn in soybean cultivars that presented similar behavior for the variable in question, even they have different characteristics.

For all cultivars, LA values were reduced under interference (Table 3); this indicates that the corn explored the same ecological niche of soybeans, competing for the same resources in

Table 3. Leaf area (LA) at 49 days after emergence (DAE) of the BMX 7166, CD 2694, TEC 5718, and TEC 6029 soybean cultivars as a function of interference conditions: total control (absence of corn during the entire cycle) and without control (corn present throughout the cycle). Cooperativa Central Gaúcha Ltda-CCGLTEC, Cruz Alta, RS, $2014 / 2015$

\begin{tabular}{|c|c|c|}
\hline \multirow[t]{2}{*}{ Cultivars } & \multicolumn{2}{|c|}{ LA $\left(\mathrm{cm}^{-2}\right.$ plant $\left.^{-1}\right)$} \\
\hline & Total control & Without control \\
\hline TEC 5718 & $3,090.59 \mathrm{~A} \mathrm{a}^{1}$ & $1,687.75 \mathrm{~A} \mathrm{~b}$ \\
\hline CD 2694 & $2,210.80 \mathrm{~B} \mathrm{a}$ & $1,609.90 \mathrm{~A} \mathrm{~b}$ \\
\hline TEC 6029 & $2,403.71 \mathrm{~B} \mathrm{a}$ & $1,778.74 \mathrm{~A} \mathrm{~b}$ \\
\hline BMX 7166 & $3,108.06 \mathrm{~A} \mathrm{a}$ & $1,710.16 \mathrm{~A} \mathrm{~b}$ \\
\hline Mean & \multicolumn{2}{|c|}{$2,199.96$} \\
\hline $\mathrm{CV}^{2}(\%)$ & \multicolumn{2}{|c|}{11.69} \\
\hline
\end{tabular}

time and space (Agostinetto et al., 2009). Besides that, natural compounds (allelochemicals) can be produced by corn in coexistence, providing the species with competitive ability and defense against pests. Among the compounds found in corn are benzoxazinoids and phenolics, as more important (Jabran, 2017). Knowledge of this allelopathic potential of corn can be used to suppress weeds in itself and other crops and is an essential tool in integrated weed management (Jabran, 2017).

It is understood that characteristics such as greater height and foliar area, as well as a high branch length and number, contribute to 
an increased competition capacity (Bianchi et al., 2006). Based on this, at the absence of interference, BMX 7166 and TEC 5718 presented higher LA values, suggesting a superiority when compared to the other cultivars used. However, under interference, this superiority did not persist (Table 3).

In terms of chlorophyll index and growth stage, were not differences between the soybean cultivars (data not shown).

The evaluation of the morphological characteristics in the field aimed to identify the cultivars with the highest growth under coexistence with corn. In this sense, CD 2694 cultivar showed the best results (Table 2). Also, BMX 7166 and TEC 5718 for the stood out in terms of LA at 49 DAE (Table 4). However, this advantage could not be maintained under coexistence. Thus, it should be emphasized that the variables evaluated (PH, LA, SDM, chlorophyll index, and GS) are usually controlled by a set of genes and are therefore highly responsive to environmental factors (Radosevich et al., 2007).

Apparent biological productivity (ABP) differed between the cultivars under interference up to the $\mathrm{V}_{6}$ stage, in which CD 2694 presented lower values than BMX 7166, and TEC 6029 (Table 4).

Table 4. Apparent biological productivity (ABP) of BMX 7166, CD 2694, TEC 5718, and TEC 6029 soybean cultivars, as a function of interference conditions: total control (absence of corn during the entire cycle), control at stages $V_{3^{\prime}} V_{6^{\prime}}$ and $V_{9}$, and without control (presence of corn during the entire cycle). Cooperativa Central Gaúcha Ltda - CCGLTEC, Cruz Alta, RS, 2014/2015

\begin{tabular}{|c|c|c|c|c|c|}
\hline \multirow[t]{2}{*}{ Cultivar } & \multicolumn{5}{|c|}{ ABP (g plant-1) } \\
\hline & Total control & Control $V_{3}$ & Control $V_{6}$ & Control $V_{9}$ & Without control \\
\hline TEC 5718 & $49.46 \mathrm{~A} \mathrm{a}$ & $47.84 \mathrm{~A} \mathrm{a}$ & $43.42 \mathrm{AB} a b$ & $42.22 \mathrm{~A} \mathrm{ab}$ & $28.12 \mathrm{~A} \mathrm{~b}$ \\
\hline CD 2694 & $40.11 \mathrm{~A} \mathrm{a}$ & $47.60 \mathrm{~A} \mathrm{a}$ & $31.63 \mathrm{~B} \quad \mathrm{a}$ & $42.03 \mathrm{~A} \mathrm{a}$ & $14.14 \mathrm{Ab}$ \\
\hline TEC 6029 & $45.95 \mathrm{~A} \mathrm{a}$ & $41.92 \mathrm{~A} \mathrm{a}$ & $53.81 \mathrm{~A} \quad \mathrm{a}$ & $37.70 \mathrm{~A} \mathrm{a}$ & $9.57 \mathrm{~A} \mathrm{~b}$ \\
\hline$B M \times 7166$ & $46.75 \mathrm{~A} \mathrm{ab}^{1}$ & $39.56 \mathrm{~A} \mathrm{~b}$ & $59.80 \mathrm{~A} \mathrm{a}$ & $52.20 \mathrm{~A} \mathrm{ab}$ & $20.92 \mathrm{~A} \mathrm{C}$ \\
\hline Mean & & & 39.50 & & \\
\hline $\mathrm{CV}^{2}(\%)$ & & & 18.04 & & \\
\hline
\end{tabular}

For the BMX 7166 cultivar, apparent biological productivity in the absence of interference differed from that of plants under interference during the entire cycle, resulting in a $55 \%$ reduction. This was also the case for cultivar CD 2694, albeit with a reduction of $65 \%$ (Table 4). For the cultivars TEC 5718 and TEC 6029, similar to the other cultivars, ABP in the absence of interference differed from the values found for growth under interference during the entire cycle.

The AHI was higher for CD 2694 and TEC 6029 by 20 and 18\%, respectively, when compared to the values obtained for TEC 5718 (Table 5). Cultivar BMX 7166 did not differ from the others in terms of $\mathrm{AHI}$. Under interference, $\mathrm{AHI}$ was reduced when the cultivars grew with interference during the entire cycle, with an average loss of $25 \%$ (Table 5). Thus, interference with corn during the entire growth cycle affected the ABP of all soybean cultivars (Table 4); the same was observed for AHI (Table 5).

At harvest time, BMX 7166 cultivar had the highest $\mathrm{PH}$ values due to its inherent high height. The lowest values were observed for TEC 5718, which is a short- plant heigth cultivar (Table $5)$.

Cultivar TEC 5718 (60.50) had the highest number of pods per plant, similar to the values found for BMX 7166 (57.27) and CD 2694 (56.28), while TEC 6029 showed the lowest values (46.31) (Table 5). However, in TEC 6029, the reduction in the number of pods per plant was $32 \%$ compared to TEC 5718. In terms of number of grains per plant, CD 2694 showed the highest values, which were similar to those found for BMX 7166 or TEC 5718. In relation to TSW, the highest increase was obtained for TEC 6029 (169.35 g) and the lowest for TEC 5718 (136.39 g) (Table 5).

The higher TSW value for cultivar TEC 6029 was in accordance with the lower number of grains per plant, suggesting an increased amount of photoassimilates per grain. The lowest TSW value was observed for TEC 5718, which, however, presented a higher number of pods per plant. In view of this, it is possible that a higher 
Table 5. Apparent harvest index (AHI), plant height (PH), total number of pods per plant (Total $n^{\circ}$ of pods plant-1), grain per plant (Grain plant-1), and thousand seed weight (TSW) of the BMX 7166, CD 2694, TEC 5718, and TEC 6029 soybean cultivars under interference, without interference, and with corn control from the $V_{3^{\prime}} V_{6^{\prime}}$ and $V_{9}$ phenological stages. Cooperativa Central Gaúcha Ltda-CCGLTEC, Cruz Alta, RS, 2014/2015

\begin{tabular}{|c|c|c|c|c|c|}
\hline Cultivar & $\mathrm{AHI}(\%)$ & $\mathrm{PH}(\mathrm{cm})$ & $\begin{array}{l}\text { Total } n^{\circ} \text { of } \\
\text { pods plant }{ }^{-1}\end{array}$ & Grains plant ${ }^{-1}$ & TSW (g) \\
\hline TEC 5718 & $32 b^{1}$ & $68.80 \mathrm{c}$ & $60.50 a$ & $134.20 a b$ & $136.39 \mathrm{C}$ \\
\hline CD 2694 & $40 a$ & $95.67 \mathrm{~b}$ & $56.28 \mathrm{ab}$ & $136.26 \mathrm{a}$ & $145.59 \mathrm{~b}$ \\
\hline TEC 6029 & $39 \mathrm{a}$ & $90.62 \mathrm{~b}$ & $46.31 \mathrm{~b}$ & $104.73 b$ & $169.35 \mathrm{a}$ \\
\hline$B M X 7166$ & $36 a b$ & $109.88 \mathrm{a}$ & $57.27 \mathrm{ab}$ & $135.66 \mathrm{ab}$ & $149.67 \mathrm{~b}$ \\
\hline Mean & 37 & 91.05 & 54.96 & 127.37 & 150.27 \\
\hline $\mathrm{CV}^{2}(\%)$ & 9.73 & 5.03 & 15.48 & 14.97 & 5.12 \\
\hline Interference & $\mathrm{AHI}(\%)$ & $\mathrm{PH}(\mathrm{cm})$ & $\begin{array}{l}\text { Total } n^{\circ} \text { of } \\
\text { pods plant }\end{array}$ & Grain plant-1 & TSW (g) \\
\hline Total control & $39 a$ & $93.14 \mathrm{~b}$ & $64.55 a$ & $148.33 a$ & $152.98 \mathrm{a}$ \\
\hline Control $V_{3}$ & $38 a$ & $91.22 \mathrm{bc}$ & $62.63 \mathrm{a}$ & $145.73 a$ & $156.14 a$ \\
\hline Control $V_{6}^{3}$ & $38 a$ & $88.09 \mathrm{~cd}$ & $61.68 a$ & $146.12 \mathrm{a}$ & $150.78 a$ \\
\hline Control $V_{9}$ & $39 a$ & $84.15 \mathrm{~d}$ & $64.41 \mathrm{a}$ & $148.43 \mathrm{a}$ & $152.90 \mathrm{a}$ \\
\hline Without control & $29 \mathrm{~b}$ & $99.60 \mathrm{a}$ & $22.17 b$ & $49.95 \mathrm{~b}$ & $138.45 \mathrm{~b}$ \\
\hline Mean & 37 & 91.05 & 54.96 & 127.37 & 150.27 \\
\hline CV (\%) & 9.73 & 5.03 & 15.48 & 14.97 & 5.12 \\
\hline
\end{tabular}

conversion ratio of photoassimilates occurred, resulting in a lower TSW (Table 5).

There was a significant reduction for the soybean plants that lived with corn during the entire cycle in relation to the other conditions of interference for the variables total number of pods plant $^{-1}$, grain plant ${ }^{-1}$, and TSW, and no difference was observed for these variables between total and partial control (Table 5). Therefore the soybean cultivars used could compensate for the resources used by corn plants (from stages $V_{3^{\prime}}$ $V_{6^{\prime}}$ and $V_{9}$ ), highlighting the phenotypic plasticity of these cultivars.

When the cultivars grew in the absence of interference, the number of branches per plant did not significantly differ among the different cultivars. The same behavior was observed for corn control in the stages $V_{6}$ and $V_{9}$ and for competition throughout the entire cycle (Table 6). When growing under interference up to stage $V_{3^{\prime}}$ a higher number of branches was observed for cultivar TEC 5718.

Without interference and with corn control at the stages $V_{3^{\prime}} V_{6^{\prime}}$ and $V_{9}$, the number of branches of the cultivar BMX 7166 was similar, while when growing under interference throughout the entire cycle, branch number was reduced by $76 \%$. This behavior was similar to that observed for the CD 2694, TEC 5718, and TEC 6029 cultivars, with a reduction in branch number by 64,62 , and $82 \%$, respectively, compared to growth without interference (Table 6).

When the plant seeks an environment free of competition for light, it grows in height; however, the increase of leaf mass is reduced, with fewer branches and thinner leaves, since the plant invests a much of its photoassimilates in the elongation of the stem (Caratti et al., 2016).

All used soybean cultivars presented a similar grain yeld when interference was absent (Table 6). However, when competing with corn up to the $V_{3}$ stage, TEC 5718 presented a decrease equivalent to 755,578 , and $532 \mathrm{~kg} \mathrm{ha}^{-1}$ when compared to the cultivars TEC 6029, CD 2694 , and BMX 7166, respectively (Table 6). When corn control was carried out in stage $V_{3}$, TEC 5718 showed a lower grain yeld, most likely because this cultivar is characterized by short plant heigth and determinate growth.

When the control was carried out in stage $\mathrm{V}_{6^{\prime}}$ a lower grain yeld was observed for $\mathrm{BMX}$ 7166 , only slightly differing from the productivities Of TEC 5718, TEC 6029, and CD 2694 (Table 7).

In view of these results, the losses caused by the occurrence of spontaneous corn plants in soybean crops are evident; however, when interference occurs up to the stage $V_{3^{\prime}}$ the losses were higher in cultivars characterized by short plant heigth, such as TEC 5718. When corn control was only performed in stage $V_{b^{\prime}}$ 
Table 6. Number of branches per plant and grain yield (kg ha-1) of the soybean cultivars BMX 7166, CD 2694, TEC 5718, and TEC 6029 as a function of interference conditions: total control (absence of corn during the entire cycle), control from stages $V_{3^{\prime}} V_{6}$, and $V_{9^{\prime}}$ and without control (presence of corn during the entire cycle). Cooperativa Central Gaúcha Ltda - CCGLTEC, Cruz Alta, RS, 2014/2015

\begin{tabular}{|c|c|c|c|c|c|}
\hline \multirow[t]{2}{*}{ Cultivar } & \multicolumn{5}{|c|}{ Number of branches per plant } \\
\hline & Total control & Control at $V_{3}$ & Control at $\mathrm{V}_{6}$ & Control at $\mathrm{V}_{9}$ & Without control \\
\hline TEC 5718 & $3.60 \mathrm{~A} \mathrm{a}^{1}$ & $3.40 \mathrm{~A} \mathrm{a}$ & $2.97 \mathrm{~A} \mathrm{a}$ & $2.92 \mathrm{~A} \mathrm{a}$ & $1.37 \mathrm{~A} \mathrm{~b}$ \\
\hline CD 2694 & $2.27 \mathrm{~A} \mathrm{a}$ & $2.12 \mathrm{~B} \mathrm{a}$ & $2.42 \mathrm{~A} \mathrm{a}$ & $3.00 \mathrm{~A} \mathrm{a}$ & $0.82 \mathrm{~A} \mathrm{~b}$ \\
\hline TEC 6029 & $2.80 \mathrm{~A} \mathrm{a}$ & $2.67 \mathrm{AB} a$ & $3.15 \mathrm{~A} \mathrm{a}$ & $2.47 \mathrm{~A} \mathrm{a}$ & $0.50 \mathrm{~A} \mathrm{~b}$ \\
\hline BMX7 166 & $2.44 \mathrm{~A} \mathrm{a}$ & $2.50 \mathrm{AB} a$ & $2.72 \mathrm{~A} \mathrm{a}$ & $2.99 \mathrm{~A} \mathrm{a}$ & $0.57 \mathrm{~A} \mathrm{~b}$ \\
\hline $\begin{array}{l}\text { Mean } \\
C^{2}(\%)\end{array}$ & & & $\begin{array}{c}2.35 \\
17.73\end{array}$ & & \\
\hline \multirow[t]{2}{*}{ Cultivar } & \multicolumn{5}{|c|}{ Grain yield $\left(\mathrm{kg} \mathrm{ha}^{-1}\right)$} \\
\hline & Total control & Control at $\mathrm{V}_{3}$ & Control at $V_{6}$ & Control at $\mathrm{V}_{9}$ & Without control \\
\hline TEC 5718 & $4,227 \quad \mathrm{~A} \mathrm{a}^{1}$ & $3,570 \quad \mathrm{~B} \mathrm{ab}$ & $3,714 \quad A B a b$ & $3,140 \quad \mathrm{Ab}$ & $717 \mathrm{AC}$ \\
\hline CD 2694 & $4,457 \quad \mathrm{~A} \mathrm{a}$ & $4,148 \mathrm{~A} \mathrm{a}$ & $4,351 \quad \mathrm{~A} \mathrm{a}$ & $3,786 \mathrm{~A} \mathrm{a}$ & $833 \mathrm{~A} \mathrm{~b}$ \\
\hline TEC 6029 & $4,097 \quad \mathrm{~A} \mathrm{ab}$ & $4,325 \mathrm{~A} \mathrm{a}$ & $3,920 \quad A B a b$ & $3,529 \mathrm{~A} \mathrm{~b}$ & $937 \mathrm{AC}$ \\
\hline BMX 7166 & $3,880 \mathrm{~A} \mathrm{a}$ & $4,102 \mathrm{~A} \mathrm{a}$ & $3,482 \quad \mathrm{~B} \mathrm{a}$ & $3,360 \mathrm{~A} \mathrm{a}$ & $644 \mathrm{~A} \mathrm{~b}$ \\
\hline Mean & & & 3252 & & \\
\hline C.V. ${ }^{2}(\%)$ & & & 8.44 & & \\
\hline
\end{tabular}

cultivars of determinate growth, medium/high plant heigth, and long cycle, such as CD 2694, tended to present lower losses in grain yield when compared to the other cultivars. However, even for cultivars with different characteristics, the losses are equivalent to those that occurred when corn control was performed at stage $V_{9}$.

The cultivars BMX 7166 and CD 2694 differed in yield only when coexistence was present throughout the entire cycle, resulting in losses of 83 and $81 \%$ for BMX 7166 and CD 2694, respectively (Table 6).

A higher grain yield was observed for TEC 5718 when it grew in the absence of interference, with similar yields when corn control was performed in stages $V_{3}$ and $V_{6}$; however, when corn control was performed at stage $V_{9^{\prime}}$ grain yeld was reduced by $26 \%$. When interference was present throughout the entire cycle, the reduction in grain yield was significantly different compared to that achieved with partial control, with a loss of $83 \%$ compared to that obtained when there was no interference. For cultivar TEC 6029, when corn growth was controlled up to stage $V_{9}$, yield loss was $14 \%$, while under interference throughout the entire cycle, grain yeld was reduced by $77 \%$ compared to growth without interference.

A corn plant density of eight plants per square meter is able to significantly reduce shoot dry mass production from 15 DAE. Under interference throughout the entire cycle, at the same plant density, soybean yields were reduced by 77 to $83 \%$, according to the cultivar, corresponding to losses between 3,160 and 3,624 $\mathrm{kg} \mathrm{ha}^{-1}$. In a similar study, 16 volunteer corn plants per square meter reduced soybean grain yield by $41 \%$, while 0.5 plants per square meter reduced yield by $10 \%$ (Marquardt et al., 2012). Evaluating the soybean yield in consortium with corn was observed lower production when competed with corn by both root and shoot systems (LV et al., 2014).

Soybean plants under competition adjust their growth according to the established crop and weed population as well as the environmental conditions such as solar radiation, humidity, and soil nutrient levels (Silva et al., 2009). However, the relationship between the ability of the plant to remove nutrients from the soil and the amounts required varies not only with the cultivar, but also with the degree of competition (Cury et al., 2012).

A large part of the impact of volunteer corn on soybean development is related to direct light competition due to the higher height (Marquardt et al., 2012). In addition, corn presents a high efficiency of interception and use of solar radiation, mainly because C4 plants present two types of cells that contain 
chloroplasts, namely mesophyll and bundle sheath cells. The latter has a higher internal $\mathrm{CO}_{2}$ concentration, allowing photosynthesis to occur even under higher temperatures and with higher light intensity amplitudes, which makes C4 plants more efficient in the use of water, solar radiation, and nutrients (Taiz, 2013).

Also, corn plants develop a highly competitive root system, allowing them to be dominant when coexisting with soybean; in this regard, it should be noted that competition in systems of different species is simultaneously affected simultaneously by soil water content, nutrient availability, and root morphology. Thus, below-ground interactions between species may affect yield more than above-ground interactions (He et al., 2012).

Based on our results, the emergence of volunteer corn plants in soybean cultivations causes a high reduction in of the crop yield. However, when weed control is performed early in the growth cycle, this effect can be minimized. An exception was the cultivar TEC 5718 (short plant heigth, determinate and rapid growth), which showed a lower production than the other cultivars, indicating that interference up to stage $V_{3}$ compromised soybean development, subsequently resulting in lower yield. We also assume that cultivars with a short height, determinate growth, and short growth cycle have a lower competitive ability in the initial stages, resulting in significant yield reduction.

In a similar study, a soybean cultivar with an extremely short growth cycle showed a high productive potential, similar to that of a cultivar with a medium growth cycle; however, in competition with Conyza bonariensis L., the first cultivar showed a considerably reduced grain yield (Trezzi et al., 2013). Thus, the advantage in using more competitive cultivars mainly lies in their competitive ability during the vegetative period, since at this stage, competitive relationships are established (Bianchi et al., 2006). However, it is interesting that a cultivar shows advantageous characteristics regarding its competitive potential at the beginning of the development, but that it can maintain these advantages throughout the growth cycle (Fleck et al., 2009).

With the possibility of planting two summer crops in some regions, producers prefer cultivars with a short growth cycle. Thus, most of the cultivars currently launched by breeders have a short cycle and indeterminate growth. However, such cultivars are more susceptible to losses when coexisting with weeds even in the initial growth stages, according to the results of the present study.

The use of cultivars with a short cycle, associated with an indeterminate growth habit, is based on the fact that the productive potential is high since the flowering period will be longer, mainly because vegetative development continues when flowering begins, which may increase the number of pods produced and thus compensate for the shorter cycle (Walter et al., 2015). However, our results are not in agreement with this hypothesis since, based on the grain yield obtained when competition occurred until $\vee_{6}$, a cultivar of determinate habit, with a long or medium/short cycle, showed a higher yield compared to the other cultivars. Thus, it is likely that characteristics such as plant heigth and cycle length influence yield, not necessarily the growth habit.

The morphophysiological characteristics of soybean cultivars related to competition capacity in the early stages vary considerably, and cultivars characterized by high plant heigth and medium/long growth cycle facilitate competition ability. However, corn plant growth is not suppressed, affecting soybean development in the absence of weed control (CARATTI et al., 2016). It was not possible to differentiate more competitive soybean cultivars when they compete with spontaneous corn plants for resources during the whole cycle, due to their highly competitive capacity.

\section{Conclusions}

The soybean cultivars used in this study were similarly affected by interference with spontaneous corn throughout the development cycle. Cultivars with a medium/long cycle, such as CD 2694 (GM: 6.9) and BMX 7166 (GM: 6.6), demonstrated a higher competitive ability when competition was present up to stage $V_{\text {, }}$ when compared to the short cycle cultivars TEC 5718 (GM: 5.9) and TEC 6029 (GM: 5.7). 
The coexistence of soybean cultivars with volunteer corn plants (8 plants $\mathrm{m}$-2) throughout the development cycle results in high crop losses, reducing grain yield by up to $83 \%$.

\section{Acknowledgment}

The authors are grateful to the Cooperativa Central Gaúcha Ltda - CCGLTEC staff; to CAPES, CNPq, and Fapergs for granting scholarships, and to the colleagues and trainees of the Graduate Program of the Universidade Federal de Pelotas-PPGFs/UFPel.

\section{References}

Agostinetto, D., Rigoli, R.P., Galon, L., Moraes, P.V.D. de, Fontana, L.C. 2009. Competitividade relativa da soja em convivência com papuã (Brachiaria plantaginea). Scientia Agraria 10: 185-190.

Agostinetto, D., Galon, I., Moraes, P.V.D., Rigoli, R.P., Tironi, S.P., Panozzo, L.E. 2008. Competitividade relativa entre cultivares de arroz irrigado e biótipo de capim-arroz (Echinochloa spp.). Planta Daninha 26: 757-766.

Ballaré, C.L. 2014. Light Regulation of Plant Defense. Annual Review of Plant Biology 65: 335363.

Ballaré, C.L. 2009. Illuminated behaviour: phytochrome as a key regulator of light foraging and plant anti-herbivore defence. Plant Cell Environ 32: 713-725.

Bastiani, M. O., Lamego, F. P., Agostinetto, D., Langaro, A. C., Silva, D. C. 2016. Relative competitiveness of soybean cultivars with barnyardgrass. Bragantia, 75: 435-445.

Bianchi, M.A, Fleck, N.G, Federizzi, L.C. 2006. Características de plantas de soja que conferem habilidade competitiva com plantas daninhas. Bragantia 65: 623-632.

Caratti, F.C. , Lamego, F.P., Silva, J.D.G., Garcia, J.R., Agostinetto, D. 2016. Partitioning of Competition for Resources Between Soybean and Corn as Competitor Plant. Planta Daninha, v: 657-665.

Correia, N.M., Durigan, J.C. 2010. Controle de plantas daninhas na cultura de soja resistente ao glifosato. Bragantia 69: 319-327.

Cury, J.P., Santos, J.B., Silva, E.B., Byrro, E.C.M., Braga, R. R., Carvalho, F.P., Valadão Silva, D. 2012. Acúmulo e partição de nutrientes de cultivares de milho em competição com plantas daninhas. Planta Daninha 30: 287-296.
EMBRAPA - Empresa Brasileira De Pesquisa Agropecuária. 2013. Milho voluntário se torna problema na safra de soja. http://www.cnpso. embrapa.br/ <Acesso em 05 jun. 2015>

Fleck, N.G., Schaedler, C.E., Agostinetto, D., Rigoli, R.P., Dal Magro, T., Tironi, S.P. 2009. Associação de características de planta em cultivares de aveia com habilidade competitiva. Planta Daninha 27: 211-220.

Franklin, K.A. 2008. Shade avoidance. New Phytologist 179: 930-944.

He, H. M., Yang, L., Zhao, L. H., Wu, H., Fan, L. M., Xie, Y., Zhu, Y. Y., Li, C.Y. 2012. The temporal-spatial distribution of light intensity in maize and soybean intercropping systems. Journal of Resources and Ecology 3: 123-132.

Jabran, K. 2017. Manipulation of allelopathic crops for weed control. Springer International Publishing. Duzce, Turkey. $87 \mathrm{p}$.

Lamego, F. P., Ruchel, Q., Kaspary, T. E., Gallon, M., Basso, C. J.; Santi, A. L. 2013. Habilidade competitiva de cultivares de trigo com plantas daninhas. Planta Daninha 31: 521-531.

Lopes, N. F. 2015. Fisiologia da produção. Viçosa, Brasil. $492 \mathrm{p}$.

LV, Y., Francis, C., Wu, P., Chen, X., Zhao, X. 2014. Maize-Soybean Intercropping Interactions Above and Below Ground. Crop science 54: 914-922.

Marquardt, P., Krupke, C., Johnson, W.G. 2012. Competition of Transgenic Volunteer Corn with Soybean and the Effect on Western Corn Rootworm Emergence. Weed Science 60: 193198.

Merotto JR., A., Fischer, A. J., Vidal, R.A. 2009. Perspectivas para usar o conhecimento da qualidade da luz como uma ferramenta de manejo de plantas daninhas ecofisiológico avançada. Planta Daninha 27: 407-419.

Moreno, J. A. 1961. Clima do Rio Grande do Sul. Secretaria da Agricultura, Diretoria de Terras e Colonização, Porto Alegre, Brasil. 46 p.

Radosevich, S.R., Hold, J.S., Ghersa, C.M. 2007. Ecology of weeds and invasive plants: relationship to agriculture and natural resource management. Wiley-Interscience, New Jersey, Estados Unidos. $400 \mathrm{p}$.

Rigoli, R.P., Agostinetto, D., Schaedler, C.E., Dal Magro, T., Tironi, S. 2008. Habilidade competitiva relativa do trigo (Triticum aestivum) em convivência com azevém (Lolium multiflorum) ou nabo (Raphanus raphanistrum). Planta Daninha 26: 93-100. 
Santos, H.G. dos, Jacomine, P.K.T., Anjos, L.H.C. dos, Oliveira, V.A. de, Lumbreras, J.F., Coelho, M.R., Almeida, J.A. de, Cunha, T.J.F., Oliveira, J.B. de. 2013. Sistema brasileiro de classificação de solos. Brasília: Embrapa, 353p.

Silva, A.F., Concenço, G., Aspiazú, I., Ferreira, E.A., Galon, L., Coelho, A.T.C.P., Silva, A.A., Ferreira, F.A. 2009. Interferência de plantas daninhas em diferentes densidades no crescimento da soja. Planta Daninha 27: 75-84.

Taiz, I., Zeiger, E. 2013. Fisiologia Vegetal. Artmed, Porto Alegre, Brasil. 918 p.

Trezzi, M.M., Balbinot JR., A.A., Benin, G., Debastiani, F., Patel, F., Miotto JR., E. 2013. Competitive ability of soybean cultivars with horseweed (Conyza bonariensis). Planta Daninha 31: 543-550.

Walter, L.C., Rosa, H.T., Streck, N.A. 2015. Mecanismos de aclimatação das plantas à elevada concentração de $\mathrm{CO}_{2}$. Ciência Rural 45: 1564-1571.

Wu, W., Fan, L.; Li, M.F., Liu, H.B., Li. Y.Q. 2012. Sensitivity analysis of crop growth models to multitemporal scale solar radiation. Transactions from the Chinese Society of Agricultural Engineering 28: 123-128. 